\title{
Methadone in the treatment of bone pain in a patient with disseminated breast cancer
}

\begin{abstract}
Treatment of pain is an important element of therapeutic management in cancer patients. The article presents the case of a patient diagnosed with breast cancer, which spread to the liver and lungs and presenting with severe bone pain syndrome caused by lumbosacral metastases. Treatment of pain with non-opioid analgesics, opioids, analgesic adjuvants and palliative radiotherapy proved ineffective. The addition of small doses of methadone to the applied pharmacotherapy produced a satisfactory analgesic effect and a significant functional improvement (an ability to move around without increased pain) as well as ensured a better quality of patient's life.
\end{abstract}

Palliat Med Pract 2020; 14, 2: 115-119

Keywords: adverse effects, methadone, opioid analgesics, pain, quality of life, treatment

\section{Introduction}

Opioids are among basic drugs used to treat moderate to severe pain in cancer patients. Opioids can be characterized by differences in pharmacodynamic, pharmacokinetic and physicochemical properties. However, in some patients, despite the appropriate use of an opioid, severe adverse effects or ineffective analgesia occur. In both cases, one opioid can be replaced by another, or another opioid can be added. Theoretical foundations for the opioid switch include incomplete cross-tolerance between opioids, differences in the rate of tolerance development concerning analgesia and adverse effects, genetically determined differences in affinity and activation of particular receptor types, different mechanisms of analgesic activity, differences in pharmacokinetics and pharmacody- namics of individual opioids, as well as interactions with other drugs [1].

The complex nature of bone pain requires the use of drugs with different mechanisms of action. Pharmacotherapy is based on the WHO three-stage pain relief ladder. Non-steroidal anti-inflammatory drugs (NSAIDs) and opioids are the medicines of choice for the treatment of bone pain, often in combination with other drugs: bisphosphonates and corticosteroids and, because of the neuropathic component, also gabapentinoids, antidepressants, NMDA receptor antagonists, lidocaine or cannabinoids. Non-pharmacological management, especially palliative radiotherapy, plays an important role [2].

Methadone is a mu- and delta receptor agonist (L-methadone), has a moderate antagonistic effect on NMDA (N-methyl-D-aspartate receptor) receptors (both enantiomers), and is serotonin and, to a lesser

\footnotetext{
Address for correspondence:

Krzysztof Nosek

Department of Pharmacology and Toxicology, Faculty of Medicine University of Warmia and Mazury in Olsztyn

Al. Warszawska 30, 11-082 Olsztyn, Poland

e-mail: hnnh@wp.pl
}

Palliative Medicine in Practice 2020; 14, 2, 115-119

Copyright (C) Via Medica, ISSN 2545-0425

DOI: 10.5603/PMPI.2020.0017 
extent, noradrenaline reuptake inhibitor ( $D$-methadone). Methadone, due to its similar affinity and higher intrinsic activity at opioid receptors in comparison to morphine and its effect on NMDA receptors and monoamine reuptake, additionally blocks G-protein more strongly and is a more potent drug than morphine.

Methadone is highly effective both in patients undergoing opioid switch to treat refractory pain and as an added therapy especially in patients with neuropathic pain [3]. Here the authors present a case of a patient with disseminated breast cancer with bone metastases and methadone as a therapy added to other opioids due to severe pain.

\section{Case report}

The patient aged 59 with right breast cancer diagnosed in 2016, after conserving surgery (July 2016), chemotherapy and adjuvant radiotherapy (April 2017), with metastases to bone, liver and lungs (in a histopathological examination: carcinoma ductale invasivum G2), remained under the care of the Home Hospice from April 2017.

On admission to the Home Hospice, the patient received, due to severe pain (NRS-8), transdermal buprenorphine in the dose of $52.5 \mu \mathrm{g} / \mathrm{h}$, prolonged-release (PR) oxycodone $20 \mathrm{mg} /$ day, zoledronic acid $4 \mathrm{mg}$ iv every 28 days, pregabalin $75 \mathrm{mg} /$ day, ketoprofen $100 \mathrm{mg} /$ day, paracetamol $3 \mathrm{~g} /$ day, and immediate-release (IR) morphine to treat breakthrough pain episodes in the dose of $60 \mathrm{mg} /$ day, which ensured effective analgesia - Numerical Rating Scale (NRS) 2-3; the patient also received lactulose. During several weeks the patient's condition remained stable. In June 2017 pain increased, mainly in the lumbar and sacral regions of the spine. Pain radiated to buttocks and lower left limb, therefore the patient was hospitalized in the Department of Neurology. Due to metastatic lesions in the sacrum found in MRI, palliative radiotherapy was applied to the area of metastatic lesions of the sacral bone, with good treatment tolerance

From August 2017 the patient was again referred to the Home Hospice, treated with transdermal fentanyl $100 \mu \mathrm{g} / \mathrm{h}$, oxycodone $20 \mathrm{mg}$ daily, PR oxycodone/naloxone $60 \mathrm{mg} / 30 \mathrm{mg}$ daily, added because of constipation, pregabalin $150 \mathrm{mg}$ daily, zoledronic acid $4 \mathrm{mg}$ iv every 28 days and laxatives. In October 2017, positron emission tomography revealed the progression of changes in the bones (sacrum, hip joints, spine), liver and lungs. From October 2017 to June 2018 the patient's general condition deteriorated gradually. Due to intensifying pain, doses of analgesics were increased: fentanyl to $150 \mu \mathrm{g} / \mathrm{h}$, oxycodone PR to $30 \mathrm{mg} /$ day, oxycodone/naloxone PR to
$40 \mathrm{mg} / 20 \mathrm{mg}$ daily, pregabalin to $450 \mathrm{mg} /$ day. Subcutaneous (sc.) morphine was instituted, gradually increased to $36 \mathrm{mg} /$ day (the patient was reluctant to take oral drugs), and duloxetine in the dose of $60 \mathrm{mg} /$ day. Additionally, dexamethasone was used, while NSAIDs, metamizole and paracetamol were used periodically. However, the efficacy of the above treatment was unsatisfactory.

In addition to pain, which at times increased to 7-8 in NRS, the patient complained of lack of appetite, decreased mood and constipation. Physical examination revealed compression pain in the area of the sacrum, lumbar spine and left hip joint; the patient had difficulty changing position while lying in bed and also moving around with a walker.

After discussing it with the patient and family, an attempt to add methadone was made. Methadone in the initial dose of $2 \mathrm{mg} 3$ times a day was administered and was gradually increased to the dose of $10 \mathrm{mg} 3$ times a day over 2 weeks. The addition of methadone significantly reduced pain intensity (NRS 2-3) and allowed the reduction of the doses: fentanyl to $100 \mu \mathrm{g} / \mathrm{h}$, oxycodone/naloxone PR to $40 \mathrm{mg} / 20 \mathrm{mg}$ daily, morphine sc. to $30 \mathrm{mg} /$ day, pregabalin to $300 \mathrm{mg} /$ day. The patient did not require any additional analgesics and adjuvants, except for the continuation of zoledronic acid iv in combination with vitamin $D_{3}$ and calcium supplementation. The reduction of pain intensity enabled the patient to move without pain and significantly improved her quality of life until death.

\section{Discussion}

In the case presented above, the patient underwent polytherapy including drugs with various mechanisms of action: non-opioid analgesics (NSAIDs and paracetamol), opioids, corticosteroids and bisphosphonates. Palliative radiotherapy was also performed. Despite the multimodal treatment, the pain was the cause of physical and mental suffering of the patient and a significant reduction in independent functioning. The use of methadone significantly reduced the severity of pain and significantly improved the quality of life of the patient. Methadone is typically recommended as the second- or third-line treatment in the case of ineffective treatment and/or intense adverse effects of other opioids of the third step of the WHO analgesic ladder [4].

Addition of small doses of methadone to the ongoing treatment with another opioid to ameliorate refractory pain, regardless of the dose of the opioid used, may be considered. Results of experimental studies suggest an analgesic synergy between L-me- 
thadone and morphine, oxycodone, and fentanyl without synergy in the Gl transit. The analgesic synergy of L-methadone with selective $\mu$-opioid drugs and differences in opioid-mediated actions suggest that these drugs may be acting via different mechanisms [5]. The effectiveness of such management was confirmed by the addition of methadone to the treatment the patient presented in the case was receiving. The addition of the drug made it possible to reduce the doses of other opioids as well as to discontinue some adjuvant analgesics, which significantly improved the quality of life of the patient. Several studies demonstrated such an approach.

In a questionnaire survey conducted in Sweden 410 patients received methadone and in $96 \%$ of these patients, methadone was added to ongoing opioid, mostly because of intense pain due to mixed nociceptive and neuropathic pain (70\%). Methadone was used for a median of 21 days, in $86 \%$ of patients until death. Mean daily methadone doses increased from $7 \mathrm{mg}$ at the start to $21 \mathrm{mg}(\mathrm{p}<0.005)$ during the last $24 \mathrm{~h}$. Corresponding morphine equivalent daily doses of other opioids were $184 \mathrm{mg}$ and $199 \mathrm{mg}$ $(p<0.05)$, respectively. Pain relief and adverse effects (no severe) were reported in $94 \%$ and $20 \%$ patients, respectively [6].

In a retrospective chart review, 80 patients with advanced cancer treated in a specialized palliative care unit who had received oral methadone in addition to another regular opioid were identified. A period of one week after initiation of methadone was analysed. The median daily methadone dose was $10 \mathrm{mg}$ during the treatment period. A total of $80 \%$ of patients had decreased pain intensity $(p<0.001)$. There was an increased risk for sedation and delirium, most pronounced in patients living 14 days or less after the start of methadone. No patient experienced respiratory depression [7].

Low-dose methadone as an adjunct to opioids in the treatment of cancer pain in palliative care patients was followed retrospectively for up to 60 days after the initiation of methadone as a co-analgesic. Patients were eligible if they were prescribed methadone as a co-analgesic for cancer pain and followed by the palliative care team. A total of 72 of the 146 subjects ( $49 \%$ ) qualified as significant responders ( $\geq 30 \%$ reduction in pain intensity). The median time to significant response was 7 days, and pain intensity on the day of methadone initiation predicted the response to treatment. The most frequently reported adverse events were drowsiness, confusion, constipation, and nausea [8].

Methadone is typically used for the management of severe pain in cancer patients which is refractory to treatment with other steps 3 opioids and after surgical procedures (second-line treatment) [9]. The drug is recommended for patients with severe adverse reactions to other opioids, such as neurotoxicity, constipation, nausea [10]. Methadone can be used as first-line treatment for cancer pain, providing effective analgesia [11]. Methadone can be used in patients with renal failure owing to its inactive metabolites and excretion mainly via the Gl tract; it is not removed during haemodialysis [12].

Methadone is metabolized in the liver and to a lesser extent in the intestinal wall with CYP2B6, CYP3A4, CYP2D6 through $\mathrm{N}$-demethylation to an inactive metabolite EDDP (2-Ethylidene-1,5-dimethyl-3,3-diphenylpyrrolidine). Methadone toxicity increases with concurrent use of benzodiazepines; hence this drugs combination is not recommended. Drugs which are cytochrome P-450 inhibitors, as well as grapefruit juice and one-time alcohol consumption may inhibit drug metabolism, increase its concentration and, consequently, cause increased adverse effects. Drugs which are cytochrome P-450 inducers, chronic alcohol consumption and cigarette smoking enhance drug metabolism and may decrease analgesia [10]. No studies were conducted on the immune profile of methadone in chronic pain patients. However, from the preclinical studies reported methadone exerted a weak immunosuppressive activity. It improves lymphocyte function, does not result in suppression of natural killer cell functions and accelerates lung cancer cell apoptosis [13].

Vomiting and nausea are less frequent than other opioids as methadone crosses the blood-brain barrier more easily and thus, inhibits the vomiting centre faster [14]. There are no active metabolites, which minimizes the risk of neurotoxicity symptoms, especially in patients with renal failure. Less constipation was also observed in comparison to morphine due to the drug's weaker peripheral action [15-17].

However, owing to tissue accumulation, a slow elimination rate and prolonged QT interval, using the drug, especially on a long-term basis, is associated with the risk of ventricular arrhythmias, such as torsade de pointes and respiratory depression [18]. Reports on hypoglycaemia have been published in recent years, especially with higher doses of the drug used, hence monitoring glucose levels during methadone treatment, especially with doses above $40 \mathrm{mg}$ per day, is recommended [19]. Recent reports suggest the possibility of prolonged delirium after administration of small doses of methadone added to another opioid [20]. Methadone dose should be carefully titrated, especially in the first days of treatment [21]. Particular caution should be exercised when establishing methadone dosing in patients previously untreated with opioids or receiving step 2 opioids, in elderly 
people, and especially in patients treated with high doses of opioids, because in these cases methadone shows a much stronger analgesic effect [22].

For the treatment of pain, which is refractory to other opioids, methadone should be considered as one of the available options, especially in patients with a neuropathic pain component and in patients with renal failure, providing there are no contraindications. Methadone treatment, due to a potential risk of serious adverse reactions, and complex pharmacokinetics, should be offered in specialist palliative medicine facilities and pain management clinics by doctors with experience in the treatment of chronic pain [23]. Future randomized studies may assess the efficacy and safety of such an approach [24].

\section{Conflict of interests}

Authors declare no conflict of interest.

\section{Funding}

This study has no funding.

No identifiable information about the patient is included in the manuscript.

\section{References}

1. Mercadante S, Bruera E. Opioid switching in cancer pain: From the beginning to nowadays. Crit Rev Oncol Hematol. 2016; 99: 241-248, doi: 10.1016/j.critrevonc.2015.12.011, indexed in Pubmed: 26806145.

2. Fallon M, Giusti R, Aielli F, et al. ESMO Guidelines Committee. Electronic address: clinicalguidelines@esmo.org, ESMO Guidelines Committee. Management of cancer pain in adult patients: ESMO Clinical Practice Guidelines. Ann Oncol. 2018; 29(Suppl 4): iv166-iv191, doi: 10.1093/annonc/mdy152, indexed in Pubmed: 30052758.

3. Porta-Sales J, Garzón-Rodríguez C, Villavicencio-Chávez C, et al. Efficacy and Safety of Methadone as a Secon$\mathrm{d}$-Line Opioid for Cancer Pain in an Outpatient Clinic: A Prospective Open-Label Study. Oncologist. 2016; 21(8): 981-987, doi: 10.1634/theoncologist.2015-0503, indexed in Pubmed: 27306912.

4. Caraceni A, Hanks G, Kaasa S, et al. Use of opioid analgesics in the treatment of cancer pain: evidence-based recommendations from the EAPC. The Lancet Oncology. 2012; 13(2): e58-e68, doi: 10.1016/s1470-2045(12)70040-2.

5. Bolan E, Tallarida R, Pasternak G. Synergy between $\mu$ Opioid Ligands: Evidence for Functional Interactions among $\mu$ Opioid Receptor Subtypes. Journal of Pharmacology and Experimental Therapeutics. 2002; 303(2): 557-562, doi: 10.1124/jpet.102.035881.

6. Fürst $\mathrm{P}$, Lundström $\mathrm{S}$, Klepstad $\mathrm{P}$, et al. The Use of Low-Dose Methadone as Add-On to Regular Opioid Therapy in
Cancer-Related Pain at End of Life: A National Swedish Survey in Specialized Palliative Care. J Palliat Med. 2020; 23(2): 226-232, doi: 10.1089/jpm.2019.0253, indexed in Pubmed: 31436477.

7. Fürst $P$, Lundström $S$, Klepstad $P$, et al. Improved Pain Control in Terminally III Cancer Patients by Introducing Low-Dose Oral Methadone in Addition to Ongoing Opioid Treatment. J Palliat Med. 2018; 21(2): 177-181, doi: 10.1089/jpm.2017.0157, indexed in Pubmed: 28792784.

8. Courtemanche F, Dao D, Gagné $F$, et al. Methadone as a Coanalgesic for Palliative Care Cancer Patients. J Palliat Med. 2016; 19(9): 972-978, doi: 10.1089/jpm.2015.0525, indexed in Pubmed: 27399839.

9. Mercadante S. Switching methadone: a 10-year experience of 345 patients in an acute palliative care unit. Pain Med. 2012; 13(3): 399-404, doi: 10.1111/j. 1526-4637.2012.01334.x, indexed in Pubmed: 22360828.

10. Palat G, Chary S. Practical Guide for Using Methadone in Pain and Palliative Care Practice. Indian J Palliat Care. 2018; 24(Suppl 1): S21-S29, doi: 10.4103/IJPC.IJPC_186_17, indexed in Pubmed: 29497251.

11. Mercadante S, Bruera E. Methadone as a First-Line Opioid in Cancer Pain Management: A Systematic Review. J Pain Symptom Manage. 2018; 55(3): 998-1003, doi: 10.1016/j. jpainsymman.2017.10.017, indexed in Pubmed: 29101087.

12. Sunilkumar MM, Lockman K. Practical Pharmacology of Methadone: A Long-acting Opioid. Indian J Palliat Care. 2018; 24(Suppl 1): S10-S14, doi: 10.4103/IJPC. IJPC 180 17, indexed in Pubmed: 29497249.

13. Franchi S, Moschetti G, Amodeo G, et al. Do All Opioid Drugs Share the Same Immunomodulatory Properties? A Review From Animal and Human Studies. Front Immunol. 2019; 10: 2914, doi: 10.3389/fimmu.2019.02914, indexed in Pubmed: 31921173.

14. Sande TA, Laird BJA, Fallon MT. The Management of Opioid-Induced Nausea and Vomiting in Patients with Cancer: A Systematic Review. J Palliat Med. 2019; 22(1): 90-97, doi: 10.1089/jpm.2018.0260, indexed in Pubmed: 30239277.

15. Mancini IL, Hanson J, Neumann CM, et al. Opioid type and other clinical predictors of laxative dose in advanced cancer patients: a retrospective study. J Palliat Med. 2000; 3(1): 49-56, doi: 10.1089/jpm.2000.3.49, indexed in Pubmed: 15859721.

16. Daeninck PJ, Bruera E. Reduction in constipation and laxative requirements following opioid rotation to methadone: a report of four cases. J Pain Symptom Manage. 1999; 18(4): 303-309, doi: 10.1016/s0885-3924(99)00086-x, indexed in Pubmed: 10534971.

17. Moulin D, Boulanger A, Clark AJ, et al. Canadian Pain Society. Pharmacological management of chronic neuropathic pain: revised consensus statement from the Canadian Pain Society. Pain Res Manag. 2014; 19(6): 328-335, doi: 10.1155/2014/754693, indexed in Pubmed: 25479151.

18. Mercadante S, Prestia G, Adile C, et al. Changes of QTc interval after opioid switching to oral methadone. Support Care Cancer. 2013; 21(12): 3421-3424, doi: 10.1007/s00520-013-1928-y, indexed in Pubmed: 23949740.

19. Flory JH, Wiesenthal AC, Thaler HT, et al. Methadone Use and the Risk of Hypoglycemia for Inpatients With Cancer 
Pain. J Pain Symptom Manage. 2016; 51(1): 79-87.e1, doi: 10.1016/j.jpainsymman.2015.08.003, indexed in Pubmed: 26342726.

20. Ikegaki J, Kizawa Y. Delirium Prolonged for Three Days after Addition of One Dose of $5 \mathrm{mg}$ Methadone to Ongoing Opioid. J Palliat Med. 2020; 23(2): 164, doi: 10.1089/jpm.2019.0433, indexed in Pubmed: 32023198.

21. Moksnes K, Dale O, Rosland JH, et al. How to switch from morphine or oxycodone to methadone in cancer patients? a randomised clinical phase II trial. Eur J Cancer. 2011; 47(16): 2463-2470, doi: 10.1016/j.ejca.2011.06.047, indexed in Pubmed: 21775131.
22. Ripamonti C, Groff L, Brunelli C, et al. Switching from morphine to oral methadone in treating cancer pain: what is the equianalgesic dose ratio? Journal of Clinical Oncology. 1998; 16(10): 3216-3221, doi: 10.1200/jco.1998.16.10.3216.

23. Nicholson $A B$, Watson GR, Derry $S$, et al. Methadone for cancer pain. Cochrane Database Syst Rev. 2017; 2: CD003971, doi: 10.1002/14651858.CD003971.pub4, indexed in Pubmed: 28177515.

24. Chalker C, O'Neill H, Cranfield F. Efficacy of low-dose and/or adjuvant methadone in palliative medicine. BMJ Support Palliat Care. 2019 [Epub ahead of print], doi: 10.1136/bmjspcare-2018-001695, indexed in Pubmed: 30952645. 


\section{Zastosowanie metadonu w leczeniu bólu kostnego u chorej z rozsianym} nowotworem piersi

Artykuł jest tłumaczeniem pracy: Nosek K., Leppert W., Puchała Ł., Pawlos A., Onichimowski D. Methadone in the treatment of bone pain in a patient with disseminated breast cancer. Palliat. Med. Pract. 2020 tom 14, nr 2: 115-119.

Należy cytować wersję pierwotną.

Pismiennictwo znajduje się na stonach 118-119.

\section{Streszczenie}

Leczenie bólu jest istotnym elementem postępowania terapeutycznego u pacjentów nowotworowych. W niniejszym artykule przedstawiono przypadek pacjentki chorującej na nowotwór piersi z przerzutami do wątroby i płuc, u której wystąpił silny zespół bólu kości spowodowany przerzutami do odcinka lędźwiowo-krzyżowego. Leczenie bólu nieopioidowymi środkami przeciwbólowymi, opioidami, adjuwantami przeciwbólowymi oraz radioterapią paliatywną okazało się nieskuteczne. Dodanie małych ilości metadonu do stosowanej farmakoterapii skutkowało zadowalającym działaniem przeciwbólowym oraz znaczną poprawą czynnościową (możliwość poruszania się bez nasilenia bólu), a także zapewniło pacjentce lepszą jakość życia. Palliat Med Pract 2020; 14, 2: 120-123

Słowa kluczowe: działania niepożądane, metadon, opioidowe środki przeciwbólowe, ból, jakość życia, leczenie

\section{Wstęp}

Leki opioidowe należą do środków wykorzystywanych w leczeniu umiarkowanego i silnego bólu u pacjentów nowotworowych. Opioidy mogą różnić się właściwościami farmakodynamicznymi, farmakokinetycznymi oraz fizykochemicznymi. Pomimo prawidłowego stosowania opioidu u niektórych pacjentów pojawiają się jednak działania niepożądane lub leczenie jest nieskuteczne. W obu przypadkach dany lek opioidowy można zamienić na inny lub dodać do niego inny opioid. Teoretyczne podstawy do zmiany leku opioidowego obejmują niepełną tolerancję krzyżową pomiędzy opioidami, różnice w szybkości rozwoju tolerancji w zakresie analgezji oraz działań niepożądanych, genetycznie uwarunkowane różnice w powinowactwie i aktywacji określonych rodzajów receptorów, różne mechanizmy działania przeciwbólowego, różnice farmakokinetyczne oraz farmakodynamiczne pomiędzy poszczególnymi opioidami, a także interakcje $z$ innymi lekami [1].

Złożony charakter bólu kości wymaga stosowania leków o różnych mechanizmach działania. Farmakoterapia opiera się na trzystopniowej drabinie analgetycznej światowej Organizacji Zdrowia (WHO, World Health Organization). Niesteroidowe leki przeciwzapalne

\footnotetext{
Adres do korespondencji:

Krzysztof Nosek

Zakład Farmakologii i Toksykologii, Wydział Medycyny Uniwersytetu Warmińsko-Mazurskiego w Olsztynie, Polska Al. Warszawska 30, 11-082 Olsztyn, Poland e-mail: hnnh@wp.pl
} 
(NLPZ) i opioidy są lekami z wyboru stosowanymi w leczeniu bólu kości, często w połączeniu z innymi środkami: bisfosfonianami i kortykosteroidami oraz, ze względu na komponentę neuropatyczną, również gabapentoidami, antydepresantami, antagonistami receptora NMDA (receptor N-metylo-D-asparaginowy), lidokainą lub kannabinoidami. Leczenie niefarmakologiczne, w szczególności radioterapia paliatywna, odgrywa istotną rolę [2].

Metadon jest antagonistą receptorów mu i delta (L-metadon), ma umiarkowane działanie antagonistyczne na receptory N-metylo-D-asparaginowe (oba enancjomery) oraz jest inhibitorem wychwytu zwrotnego serotoniny i - w mniejszym stopniu - noradrenaliny (D-metadon). Z uwagi na podobne powinowactwo i wyższą aktywność wewnętrzną na receptorach opioidowych w porównaniu z morfiną oraz jego działanie na receptory NMDA, a także na wychwyt zwrotny monoaminy, metadon dodatkowo silniej blokuje białko $\mathrm{G}$ i jest silniejszym lekiem niż morfina.

Metadon jest wysoce skuteczny u pacjentów, u których ma miejsce zmiana opioidów w celu leczenia opornego bólu, oraz jako terapia dodatkowa, szczególnie w przypadku pacjentów z bólami neuropatycznymi [3]. W niniejszym artykule przedstawiono przypadek pacjentki z rozsianym rakiem piersi z przerzutami do kości, u której zastosowano metadon jako leczenie dodatkowe do innych opioidów ze względu na silny ból.

\section{Opis przypadku}

Pacjentka w wieku 59 lat ze zdiagnozowanym w 2016 roku rakiem prawej piersi po operacji zachowawczej (lipiec 2016), chemioterapii i radioterapii adjuwantowej (kwiecień 2017) z przerzutami do kości, wątroby i płuc (w badaniu histopatologicznym: rak przewodowy inwazyjny, G2), znajdowała się pod opieką hospicjum domowego od kwietnia 2017 roku.

Po rozpoczęciu opieki w hospicjum domowym, ze względu na silny ból (skala numeryczna [NRS, Numerical Rating Scale] 8), pacjentka otrzymywała buprenorfinę $\mathrm{w}$ dawce 52,5 $\mu \mathrm{g} / \mathrm{godz}$., oksykodon o przedłużonym uwalnianiu w dawce $20 \mathrm{mg} /$ dobę, dożylnie kwas zoledronowy w dawce $4 \mathrm{mg}$ co $28 \mathrm{dni}$, pregabalinę $w$ dawce $75 \mathrm{mg} /$ dobę, ketoprofen $w$ dawce $100 \mathrm{mg} /$ dobę, paracetamol $\mathrm{w}$ dawce $3 \mathrm{~g} / \mathrm{dzień}$ oraz morfinę o natychmiastowym uwalnianiu $w$ celu leczenia epizodów bólowych o bardzo dużym nasileniu w dawce $60 \mathrm{mg} /$ dobę, co zapewniło skuteczne działanie przeciwbólowe - 2-3 punkty w skali NRS; pacjentka otrzymywała też laktulozę. Przez kilka tygodni stan pacjentki był stabilny. W lipcu 2017 roku ból nasilił się głównie w odcinku lędźwiowym i krzyżowym kręgosłupa. Ponieważ ból promieniował do poślad- ków i lewej kończyny dolnej, chora została przyjęta na oddział neurologii. Po stwierdzeniu w rezonansie magnetycznym zmian przerzutowych w kości krzyżowej zastosowano $w$ ich obszarze radioterapię paliatywną. Pacjentka dobrze tolerowała leczenie.

Od sierpnia 2019 roku pacjentka ponownie została objęta opieką hospicjum domowego i była leczona fentanylem w dawce $100 \mu \mathrm{g} / \mathrm{godz}$., podawanym przezskórnie, oksydonem w dawce $20 \mathrm{mg} /$ dobę, oksykodonem/naloksonem o przedłużonym uwalnianiu w dawce $60 \mathrm{mg} / 30 \mathrm{mg} /$ dobę, dodanym ze względu na zatwardzenia, pregabaliną w dawce $150 \mathrm{mg} /$ dobę, kwasem zoledronowym $\mathrm{w}$ dawce $4 \mathrm{mg}$ dożylnie co 28 dni i środkami przeczyszczającymi. W październiku 2017 roku pozytonowa tomografia emisyjna wykazała postęp zmian w kościach (krzyżowej, stawach biodrowych, kręgosłupie), wątrobie i płucach. Od października 2017 do czerwca 2018 roku ogólny stan pacjentki stopniowo się pogarszał. Ze względu na narastający ból zwiększono dawki środków przeciwbólowych: fentanylu do $150 \mu \mathrm{g} / \mathrm{godz}$., oksykodonu o przedłużonym uwalnianiu do $40 \mathrm{mg} / 20 \mathrm{mg} /$ dobę, pregabaliny do $450 \mathrm{mg} /$ dobę. Wprowadzono podawaną podskórnie morfinę, stopniowo zwiększając jej dawkę do $36 \mathrm{mg} /$ dobę (pacjentka niechętnie przyjmowała leki doustne) i duloksetynę w dawce $60 \mathrm{mg} /$ dobę. Dodatkowo zastosowano deksametazon, a NLPZ, metamizol i paracetamol stosowano okresowo. Skuteczność powyższego leczenia była jednak niezadowalająca.

Poza bólem, który niekiedy nasilał się do 7-8 punktów w skali NRS, pacjentka uskarżała się na brak apetytu, obniżony nastrój i zaparcia. W badaniu fizykalnym wykryto uciskający ból w obszarze kości krzyżowej, kręgosłupa lędźwiowego oraz lewego stawu biodrowego; pacjentka miała trudności ze zmianą pozycji podczas leżenia w łóżku i poruszania się z chodzikiem.

Po rozmowie z pacjentką i jej rodziną podjęto próbę dodania do leczenia metadonu. Podano go w początkowej dawce 2-3 mg/dobę, która była stopniowo zwiększana do dawki $10 \mathrm{mg} 3$ razy na dobę przez 2 tygodnie. Dodatek metadonu znacznie zmniejszył nasilenie bólu (NRS 2-3), co pozwoliło na zmniejszenie dawek leków: fentanylu do $100 \mu \mathrm{g} / \mathrm{godz}$., oksykodonu/naloksonu o przedłużonym uwalnianiu do $40 \mathrm{mg} / 20 \mathrm{mg} /$ dobę, morfiny podawanej podskórnie do $30 \mathrm{mg} /$ dobę, pregabaliny do $300 \mathrm{mg} /$ dobę. Pacjentka nie wymagała podania dodatkowych leków przeciwbólowych ani adjuwantów, poza kontynuowanym leczeniem kwasem zoledronowym podawanym dożylnie w połączeniu z suplementacją witaminy $D_{3}$ i wapnia. Zmniejszenie nasilenia dolegliwości bólowych pozwoliło pacjentce poruszać się bez odczuwania bólu i znacznie poprawiło jej jakość życia aż do śmierci. 


\section{Dyskusja}

W przedstawionym przypadku pacjentkę poddano politerapii obejmującej leki o różnych mechanizmach działania: nieopioidowe analgetyki (NLPZ i paracetamol), opioidy, kortykosteroidy i biofosfoniany. Zastosowano u niej również radioterapię paliatywną. Pomimo leczenia multimodalnego, ból stał się przyczyną cierpienia fizycznego i psychicznego pacjentki i znacznie ograniczył jej samodzielne funkcjonowanie. Wykorzystanie metadonu znacznie zmniejszyło nasilenie bólu i istotnie poprawiło jakość życia chorej. Metadon jest zazwyczaj rekomendowany jako lek drugiego lub trzeciego wyboru w przypadkach, w których leczenie jest nieskuteczne i/lub występują silne działania niepożądane innych opioidów stanowiących trzeci stopień drabiny analgetycznej WHO [4].

Można rozważyć dodanie niewielkich dawek metadonu do trwającego leczenia innym opioidem w celu złagodzenia opornego bólu, niezależnie od stosowanej dawki opioidu. Wyniki badań eksperymentalnych sugerują synergię analgetyczną pomiędzy L-metadonem i morfiną, oksykodonem oraz fentanylem bez synergii w tranzycie przez przewód pokarmowy. Synergia analgetyczna L-metadonu z selektywnymi $\mu$-opioidami oraz różnice $w$ działaniach, w których pośredniczą opioidy, sugerują, że leki te działają poprzez różne mechanizmy [5]. Efektywność takiego postępowania potwierdzono, dodając metadon do leczenia, którym objęto opisywaną pacjentkę. Dodanie leku umożliwiło zmniejszenie dawek innych opioidów oraz zaprzestanie stosowania niektórych adjuwantowych środków przeciwbólowych, co znacząco poprawiło jakość życia chorej. Takie podejście zostało przedstawione w kilku badaniach.

W badaniu ankietowym przeprowadzonym w Szwecji metadon był przyjmowany przez 410 pacjentów; u 96\% chorych dodano go do przyjmowanego opioidu, głównie ze względu na silny mieszany ból nocyceptywny i neuropatyczny (70\%). Metadon stosowano średnio przez 21 dni, u 86\% pacjentów do śmierci. Średnie dawki dzienne metadonu zwiększono z początkowych $7 \mathrm{mg}$ do $21 \mathrm{mg}$ ( $\mathrm{p}<0,005)$ w ciągu ostatnich 24 godzin. Analogiczne dzienne dawki ekwiwalentu morfiny wynosiły odpowiednio $184 \mathrm{mg}$ i 199 mg ( $p<0,05)$. Zmniejszenie bólu i działania niepożądane (brak poważnych działań niepożądanych) wystąpiły u odpowiednio 94 i 20\% pacjentów [6].

W retrospektywnym przeglądzie zidentyfikowano 80 pacjentów z zaawansowaną chorobą nowotworową, leczonych w specjalistycznych ośrodkach opieki paliatywnej, którzy otrzymywali metadon dodatkowo, oprócz innego, standardowego opioidu. Analizowano okres jednego tygodnia po rozpoczęciu podawa- nia metadonu. Średnia dzienna dawka metadonu w okresie leczenia wynosiła $10 \mathrm{mg}$. Nasilenie bólu zmniejszyło się u łącznie $80 \%$ pacjentów $(p<0,001)$. Istniało zwiększone ryzyko wystąpienia sedacji i delirium. Ryzyko to było najwyższe u tych pacjentów, którzy żyli jeszcze przez 14 dni po rozpoczęciu leczenia metadonem bądź krócej. U żadnego z pacjentów nie wystąpiła depresja oddechowa [7].

Podawanie małej dawki metadonu jako dodatku do opioidów w leczeniu bólu nowotworowego było obserwowane retrospektywnie przez 60 dni po rozpoczęciu stosowania metadonu jako dodatkowego środka przeciwbólowego. Pacjenci kwalifikowali się, jeżeli przepisano im metadon jako drugi środek przeciwbólowy w leczeniu bólu nowotworowego i znajdowali się pod obserwacją zespołu opieki paliatywnej. Łącznie 72 spośród 146 chorych (49\%) zakwalifikowało się jako pacjenci, u których odpowiedź kliniczna była istotna ( $\geq 30 \%$ obniżenie nasilenia bólu). Średni czas na uzyskanie istotnej odpowiedzi klinicznej wynosił 7 dni, a intensywność bólu w dniu rozpoczęcia leczenia metadonem prognozowała odpowiedź na leczenie. Najczęściej zgłaszanymi działaniami niepożądanymi była senność, splątanie, zaparcia i nudności [8].

Metadon stosuje się standardowo w leczeniu silnego bólu u pacjentów nowotworowych, u których jest on oporny na leczenie innymi lekami trzystopniowej drabiny analgetycznej, oraz po zabiegach chirurgicznych (leczenie drugiego rzutu) [9]. Lek zalecany jest chorym, u których występują silne reakcje niepożądane na inne opioidy, takie jak neurotoksyczność, zaparcia i nudności [10]. Metadon może być leczeniem pierwszego rzutu w przypadku bólu nowotworowego i jest lekiem, który zapewnia skuteczne działanie przeciwbólowe [11]. Ze względu na nieaktywne metabolity oraz wydzielanie leku głównie przez przewód pokarmowy, metadon może być stosowany u pacjentów z niewydolnością nerek; nie jest on usuwany podczas hemodializy [12].

Metadon jest metabolizowany w wątrobie i - w mniejszym stopniu - w ścianie jelita za pomocą CYP2B6, CYP3A4, CYP, 2D6 poprzez N-demetylację do nieaktywnego metabolitu EDDP (2-etylideno-1,5-dimetylo-3,3-difenylo-pirolidyna). Toksyczność metadonu zwiększa się przy jednoczesnym stosowaniu benzodiazepin, toteż nie zaleca się ich łączenia. Leki, które są inhibitorami cytochromu P-450 oraz sok grejpfrutowy i jednorazowe spożycie alkoholu mogą hamować metabolizm leku, zwiększać jego stężenie i, w rezultacie, nasilić działania niepożądane. Leki, które są induktorami cytochromu P-450, długotrwałe spożywanie alkoholu i palenie tytoniu zwiększają metabolizm leku i mogą obniżać działanie przeciwbólowe [10]. Nie prowadzono badań nad profilem immunologicznym 
metadonu u pacjentów cierpiących na przewlekły ból. Niemniej jednak, z badań przedklinicznych wynika, że metadon wykazuje słabe działanie immunosupresyjne. Poprawia funkcję limfocytów, nie powoduje tłumienia naturalnych funkcji komórek o działaniu cytotoksycznym i przyspiesza apoptozę komórek raka płuc [13].

Ponieważ metadon łatwiej przenika przez barierę krew-mózg, a zatem szybciej hamuje ośrodek wymiotny, wymioty i nudności występują podczas jego stosowania rzadziej niż w przypadku innych opioidów. Nie występują aktywne metabolity, co minimalizuje ryzyko wystąpienia objawów neurotoksyczności, w szczególności u pacjentów z niewydolnością nerek. Obserwowano również mniejsze zaparcia w porównaniu z morfiną, ze względu na słabsze działanie obwodowe leku [15-17].

Jednakże, ze względu na gromadzenie się leku w tkankach, wolne tempo usuwania leku i wydłużony odstęp QT, stosowanie leku — szczególnie długoterminowo - wiąże się z ryzykiem wystąpienia arytmii komorowych, takich jak torsade de pointes i depresji oddechowej [18]. Z uwagi na fakt, że w ostatnich latach pojawiły się doniesienia o hipoglikemii, szczególnie w przypadkach stosowania większych dawek leku, należy monitorować stężenie glukozy podczas leczenia metadonem, w szczególności w przypadku dawek przekraczających $40 \mathrm{mg} /$ dobę [19]. Ostatnie doniesienia sugerują, że istnieje ryzyko wystąpienia przedłużającego się delirium po podaniu małych dawek metadonu dodanego do innego opioidu [20].
Metadon powinien być precyzyjnie miareczkowany, w szczególności w pierwszych dniach leczenia [21]. Szczególną ostrożność należy zachować podczas ustalania dawki u pacjentów, którzy nie byli wcześniej leczeni opioidami lub otrzymywali leki 2 stopnia, u osób starszych, oraz, w szczególności, u chorych leczonych dużymi dawkami opioidów, ponieważ u tych osób metadon wykazuje znacznie silniejsze działanie przeciwbólowe [22].

Metadon powinien być rozważony jako jedna $z$ dostępnych opcji leczenia bólu opornego na inne leki opioidowe, szczególnie u pacjentów z neuropatyczną komponentą bólową oraz pacjentów z niewydolnością nerek, pod warunkiem że nie istnieją przeciwwskazania. Ze względu na potencjalne ryzyko wystąpienia działań niepożądanych oraz złożoną farmakokinetykę, leczenie przewlekłego bólu metadonem powinno być prowadzone w specjalistycznych placówkach medycyny paliatywnej [23]. Przyszłe randomizowane badania mogą ocenić skuteczność i bezpieczeństwo takiego podejścia [24].

\section{Konflikt interesów}

Autorzy deklarują brak konfliktu interesów

\section{Finansowanie}

Badanie nie było finansowane.

Manuskrypt nie zawiera informacji, które mogłyby umożliwić identyfikację pacjenta. 